\title{
KETAHANAN DAN PENGARUH FITOTOKSIK CAMPURAN EKSTRAK PIPER RETROFRACTUM DAN ANNONA SQUAMOSA PADA PENGUJIAN SEMI LAPANGAN
}

\author{
Dadang $^{1}$, Nur Isnaeni ${ }^{1}$ dan Kanju Ohsawa ${ }^{2}$
}

\begin{abstract}
Persistence and Phytotoxic Effect of Extract Mixtures of Piper retrofractum (Piperaceae) and Annona squamosa (Annonaceae) in Semi Field Test. Novel strategy in vegetable pest control program is necessary to be conducted to reduce high rate of synthetic insecticide use. Botanical insecticides offer one of alternatives. Prior to be applied in the field, it has to be evaluated the extract persistence and phytotoxic effect to crops. So, the objective of this research was to study the persistence and phytotoxic effect of extract mixtures of Piper retrofractum (Piperaceae) and Annona squamosa (Annonaceae) in semi field test. Extract mixtures were sprayed on broccoli plants, then at 0,1,2,3,5,7, and 10 days after exposure under sunlight, leaves of broccoli were served to Crocidolomia pavonana (Lepidoptera: Pyralidae) to evaluate the insecticidal activity. The mortality activity of extract mixtures at $0.1 \%$ were still high until 10 days exposure. Moreover, no phytotoxic effect was occurred on broccoli plants treated with extract mixtures as high as at $0.1 \%$ of extract mixture concentration.
\end{abstract}

Key words: Annona squamosa, mortality, persistence, phytotoxic, Piper retrofractum.

\section{PENDAHULUAN}

Crocidolomia pavonana (F.) (Lepidoptera: Pyralidae) merupakan salah satu hama yang sangat merusak pada tanaman famili Brassicaceae (Sastrosiswojo \& Setiawati, 1992). Lebih dari 60\% kerusakan pertanaman kubis di Jawa Barat disebabkan oleh serangan $C$. pavonana bersama-sama dengan Plutella xylostella (L.) (Lepidoptera: Yponomeutidae) dan penyakit busuk akar (Rauf, 2005). Bahkan kehilangan hasil panen kubis akibat serangan $C$. pavonana dan P. xylostella dapat mencapai $100 \%$ apabila tidak dilakukan pengendalian (Uhan, 1993; Sastrosiswojo 1996). Walau dalam Peraturan Pemerintah No. 6 tahun 1995 dinyatakan bahwa perlindungan tanaman di Indonesia menggunakan sistem pengendalian hama terpadu (PHT), namun kenyataan di lapangan menunjukkan bahwa penggunaan insektisida masih menjadi pilihan utama dengan intensitas aplikasi yang tinggi. $95,5 \%$ petani sayuran tergantung pada penggunaan pestisida untuk pengendalian hama dan penyakit (Gusfi, 2002), bahkan tidak sedikit petani yang mengaplikasikan insektisida sintetik sebagai tindakan jaga-jaga (preventif) agar tidak terserang hama dan penyakit sehingga aplikasi insektisida sintetik menjadi sangat tinggi (Rauf et al., 2005). Penggunaan insektisida sintetik yang tidak bijaksana dapat menimbulkan dampak negatif.

Sebagai upaya untuk mengatasi permasalahan penggunaan insektisida sintetik yang tinggi, hingga kini terus dicari cara pengendalian yang lebih aman. Salah satu upaya yang dapat dilakukan adalah melalui pemanfaatan tumbuhan sebagai insektisida botani. Beberapa ekstrak yang telah menunjukkan efektifitas yang tinggi diantaranya adalah Annona squamosa (Annonaceae) dan Piper retrofractum (Piperaceae). Senyawa aktif $A$. squamosa, yaitu squamosin dan asimisin yang termasuk dalam golongan asetogenin diketahui mempunyai efek mematikan pada berbagai spesies serangga termasuk C. pavonana (Dadang, 1999). Senyawa aktif ekstrak Piperaceae memiliki kerja yang cepat pada serangga dan sangat efektif untuk beberapa serangga yang menunjukkan resistensi terhadap piretroid (Dadang, 1999).

Pengujian awal bahan insektisida botani dilakukan di laboratorium sebelum digunakan di lapangan dan setelah tersedianya formulasi, berbagai pertimbangan keamanan harus teruji (Syahputra, 2004). Karena itu, aspek keamanan pertama yang harus diketahui adalah ada tidaknya pengaruh fitotoksik bila bahan tersebut akan digunakan dalam

\footnotetext{
${ }^{1}$ Departemen Proteksi Tanaman, Fakultas Pertanian, IPB, Jl. Kamper, Kampus IPB Darmaga, Bogor 16680

${ }^{2}$ Dept. Bioscience, Faculty of Applied Bioscience, Tokyo University of Agriculture, 1-1-1 Sakuragaoka, Setagaya-ku, Tokyo 156-2560
} 
pengendalian hama pertanian. Sebagai contoh, ekstrak beberapa spesies Zingiberaceae aktif terhadap serangga tertentu tetapi ternyata juga menyebabkan fitotoksik pada tanaman, sehingga penelitian tidak ditindaklanjuti (Prijono, 1999). Dengan adanya pertimbangan di atas, penelitian ini bertujuan untuk mempelajari persistensi campuran ekstrak buah $P$. retrofractum dan biji $A$. squamosa dan mengevaluasi tingkat keamanan pada tanaman brokoli pada skala semi lapangan yang merupakan penelitia lanjutan yang dilakukan oleh Dadang et al. (2007).

\section{METODE PENELITIAN}

Tumbuhan Sumber Ekstrak. Bahan tumbuhan yang diuji adalah buah Piper retrofactum (Piperaceae) dan biji Annona squamosa (Annonaceae) yang diperoleh dari Kebun Raya Bogor. Bahan tumbuhan ini dikeringanginkan selama kurang lebih satu minggu.

Penanaman Brokoli. Benih brokoli yang digunakan adalah varietas Pilgrim. Benih brokoli terlebih dahulu disemai dalam wadah penyemaian yang berisi tanah dan pupuk kandang steril yang telah tercampur rata. Setelah berumur 3 minggu, sebanyak satu bibit dipindahkan ke tiap polybag berukuran besar (5 liter) yang telah berisi campuran tanah dan pupuk kandang. Pemupukan tambahan dilakukan ketika brokoli yang ditanam sudah mulai berumur 3-4 minggu melalui pemberian pupuk NPK dengan dosis $1 \mathrm{~g}$ per tanaman. Pemeliharaan tanaman brokoli yang dilakukan meliputi penyiraman, penyulaman, penyiangan gulma, dan pengendalian hama secara mekanik jika ada pada tanaman. Setelah berumur 2 bulan tanaman dapat digunakan sebagai pakan larva C. pavonana.

Pemeliharaan Serangga Uji . Serangga $C$. pavonana yang digunakan dalam penelitian ini merupakan koloni yang diperbanyak di Laboratorium Fisiologi dan Toksikologi Serangga, Departemen Proteksi Tanaman, Faperta IPB. Imago C. pavonana dipelihara pada kurungan serangga $(40 \mathrm{~cm} \times 40 \mathrm{~cm} \times 40 \mathrm{~cm})$ yang berdinding kain kasa dan plastik. Imago diberi pakan larutan madu $10 \%$ yang diserapkan pada segumpal kapas. Batang daun brokoli bebas pestisida dimasukkan ke dalam tabung film yang berisi air kemudian diletakkan dalam kurungan sebagai tempat peletakkan telur. Kelompok telur yang didapat diletakkan dalam cawan petri berdiameter $15 \mathrm{~cm}$ yang dialasi kertas isap. Setelah telur menetas, larva dipindahkan ke dalam kotak plastik $(35 \mathrm{~cm}$ x $25 \mathrm{~cm}$ x $5 \mathrm{~cm}$ ) yang dialasi kertas isap dan diberikan pakan daun brokoli bebas pestisida. Larva instar tua dipindahkan ke dalam kotak plastik lain yang telah diberi serbuk gergaji steril sebagai media berpupa. Pupa-pupa yang terbentuk kemudian diletakkan dalam kurungan untuk dibiarkan menjadi imago. Untuk uji hayati digunakan larva $C$. pavonana instar II awal.

Pembuatan Sediaan Ekstrak. Masing-masing bagian tanaman dikeringanginkan kemudian dipotong menjadi bagian-bagian kecil lalu digiling menggunakan blender hingga menjadi serbuk dan diayak menggunakan pengayak kasa berjalin $1 \mathrm{~mm}$. Masing-masing serbuk spesies tumbuhan direndam dalam metanol dengan perbandingan 1:10 (w/v) selama 48 jam. Rendaman masing-masing serbuk spesies tumbuhan kemudian disaring menggunakan corong Buchner yang dialasi kertas saring. Hasil saringan kemudian diuapkan dengan mengunakan rotary evaporator pada suhu $50{ }^{\circ} \mathrm{C}$ dan tekanan 400 $450 \mathrm{mmHg}$ sehingga diperoleh ekstrak kasar. Metanol hasil penguapan yang diperoleh digunakan kembali untuk membilas residu pada corong buchner yang dilakukan 3-4 kali. Ekstrak yang diperoleh setelah penguapan disimpan dalam lemari es $\left(-4^{\circ} \mathrm{C}\right)$ hingga saat digunakan.

Uji Persistensi. Ekstrak $P$. retrofactum dan $A$. squamosa (PA) dicampur dengan perbandingan 3:7 dan $1: 1(\mathrm{w} / \mathrm{w})$ pada konsentrasi $0,05 \%$ dan $0,1 \%$ (PA $3: 70,05 \%$; PA $3: 70,1 \%$; PA $1: 10,1 \%$; PA $1: 1$ 0,05\%). Ekstrak kasar tanaman tersebut diencerkan dengan metanol $1 \%$ dan Latron $77 \mathrm{~L} 0,1 \%$. Sebagai pembanding digunakan insektisida piretroid sintetik deltamethrin (nama dagang Decis 2,5 EC). Penyiapan insektisida pembanding dilakukan pada konsentrasi anjuran formulasi yaitu $0,4 \mathrm{ml} / \mathrm{l}$. Sebagai kontrol digunakan aquades yang mengandung metanol dan Latron 77L masing-masing $1 \%$ dan $0,1 \%$.

Pengujian persistensi dilakukan melalui penyemprotan insektisida menggunakan hand sprayer bertekanan pada tanaman brokoli yang ditanam pada polybag di luar ruangan. Semua daun brokoli disemprot pada permukaan atas dan bawah hingga merata. Tanaman kemudian dijemur selama \pm 7 jam/hari, yaitu dari pukul 08.00 hingga pukul 
15.00.WIB. Jika hujan tanaman dipindahkan ke tempat yang terlindung.

Daun brokoli diambil pada 0,1,2,3,5,7, dan 10 hari setelah penyemprotan lalu dipotong menjadi potong daun berbentuk segi empat $(4 \mathrm{~cm} \mathrm{x} 4 \mathrm{~cm})$. Daun yang telah dipotong kemudian dimasukkan ke dalam cawan petri yang dialasi kertas isap. Sebanyak 10 larva $C$. pavonana instar II awal dimasukkan ke dalam cawan yang telah diberi potongan daun brokoli. Larva dibiarkan makan hingga daun habis, kemudian larva diberi potongan daun brokoli bebas pestisida. Mortalitas larva dicatat pada 1, 2, dan 3 hari setelah perlakuan (hsp). Data kemudian diolah dengan program SAS (SAS Institute 1990) dilanjutkan dengan uji Duncan pada taraf 0,05\% (Steel \& Torrie 1993).

Uji fitotoksisitas. Pengujian fitotoksisitas dilakukan melalui pengolesan insektisida pada tanaman brokoli yang ditanam pada polybag. Pengolesan menggunakan kuas baik pada daun tua maupun daun muda. Setiap helai daun diolesi campuran PA 3:7 0,05\%; PA 3:7 0,1\%; PA 1:1 0,05\%; PA 1:1 0,1\% berbentuk bulatan-bulatan kecil berdiameter $1 \mathrm{~cm}$.

Gejala fitotoksisitas diamati mulai 1 hari setelah pengolesan hingga hari ke-10 pemaparan tanaman brokoli. Pengamatan dilakukan dengan cara mengamati bagian helai daun yang mengalami nekrosis atau pengerutan.

\section{HASIL}

Dalam pengujian ini baik untuk mengetahui tingkat persistensi maupun pengaruh fitotoksik dilakukan dalam skala semi lapangan sebelum direkomendasikan untuk aplikasi di lapangan. Faktor utama yang dipelajari adalah pengaruh sinar matahari terhadap ketahanan atau efikasi ekstrak yang diaplikasikan pada tanaman brokoli, sedangkan untuk pengaruh pencucian seperti pengaruh hujan sementara dikesampingkan atau tidak dipelajari.

Uji Persistensi. Pemaparan 0 hari perlakuan campuran ekstrak tanaman pada semua konsentrasi menunjukkan kematian larva kurang dari $50 \%$ pada 1 hsp namun terjadi peningkatan kematian hingga mencapai $100 \%$ pada 2 dan 3 hsp kecuali pada perlakuan ekstrak PA 1:1 0,05\% yang hanya menyebabkan kematian $89,7 \%$. Pengaruh campuran ekstrak tanaman terhadap mortalitas larva berbeda nyata jika dibandingkan dengan insektisida pembanding deltametrin. Kematian larva pada perlakuan insektisida sintetik ini sangat rendah yaitu 5\%, bahkan hingga 3 hsp hanya memberikan kematian $5,1 \%$ (Gambar 1).

Penurunan aktivitas campuran ekstrak tanaman mulai tampak pada tanaman yang dipaparkan 1 hari kecuali pada perbandingan $3: 7 \quad 0,1 \%$ yang

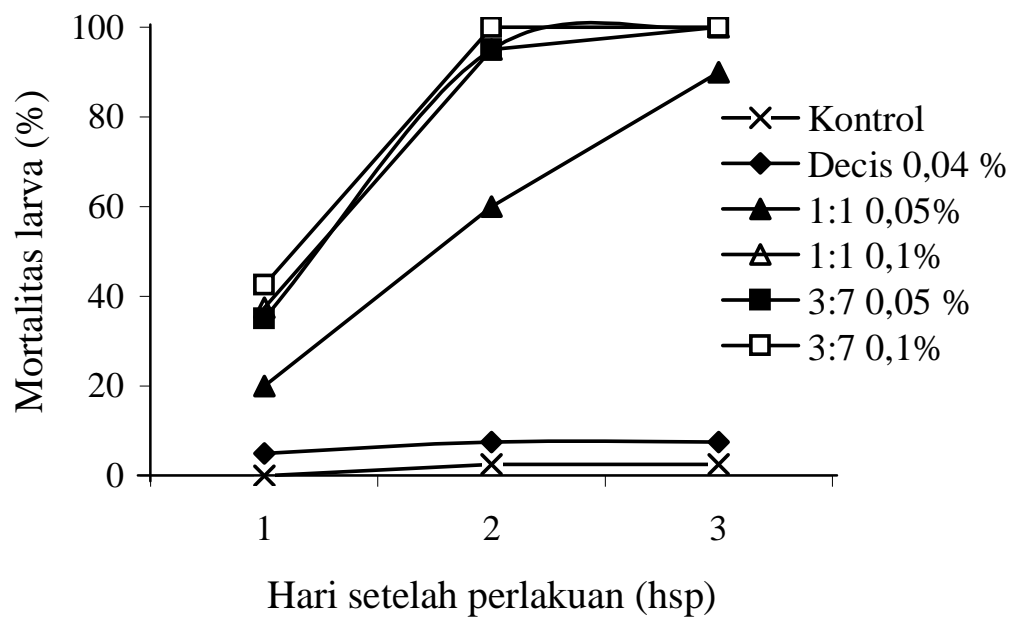

Gambar 1. Perkembangan mortalitas larva $C$. pavonana yang diperlakukan campuran ekstrak $P$. retrofractum dan A. squamosa dan insektisida pembanding pada hari ke-0 pemaparan 
menunjukkan kematian larva $100 \%$ pada 2 hsp. Kematian larva tidak berbeda nyata antara perlakuan PA 1:1 0,1\% dan PA 3:7 0,05\% yang menunjukkan persen kematian lebih dari $70 \%$ pada 3 hsp. Kematian larva terendah ditunjukkkan pada perlakuan ekstrak tanaman PA 1:1 0,05\% yang hanya menyebabkan kematian kurang dari 50\% hingga 3 hsp. Sementara itu perlakuan insektisida deltametrin menunjukkan adanya peningkatan kematian larva hingga $18,42 \%$ dibanding hari pemaparan sebelumnya (Gambar 2).

Pemaparan 2 hari menunjukkan bahwa campuran ekstrak PA 1:1 0,1\% dan PA 3:7 0,1\% menunjukkan mortalitas larva yang tidak berbeda nyata. Pada 1 hsp kedua perlakuan tersebut menunjukkan kematian larva kurang dari 50\%, sedangkan pada 2 hsp meningkat hingga mencapai $100 \%$. Hal ini berbeda nyata dengan campuran ekstrak PA 1:1 $0,05 \%$ dan PA 3:7 $0,05 \%$ yang belum menunjukkan adanya kematian larva pada 1 hsp, namun pada 3 hsp terjadi peningkatan mortalitas walaupun masih di bawah 60\%. Sementara itu insektisida pembanding menunjukkan kematian larva

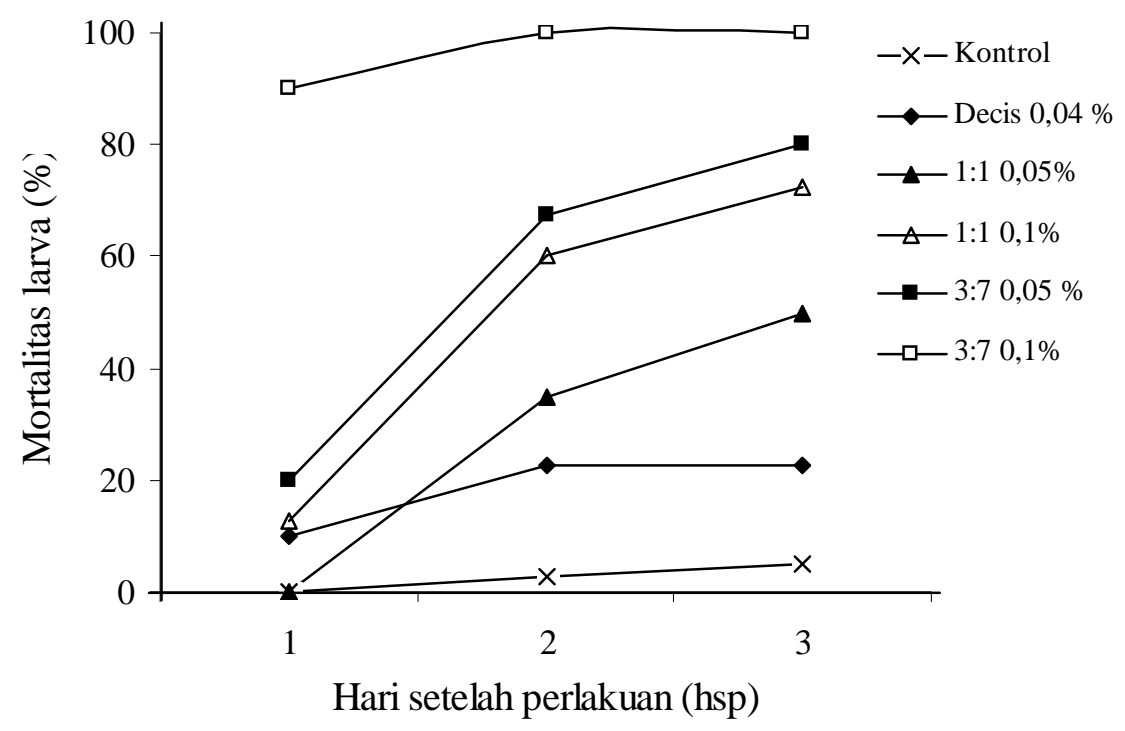

Gambar 2. Perkembangan mortalitas larva $C$. pavonana yang diperlakukan campuran ekstrak $P$. retrofractum dan A. squamosa dan insektisida pembanding pada hari ke-1 pemaparan

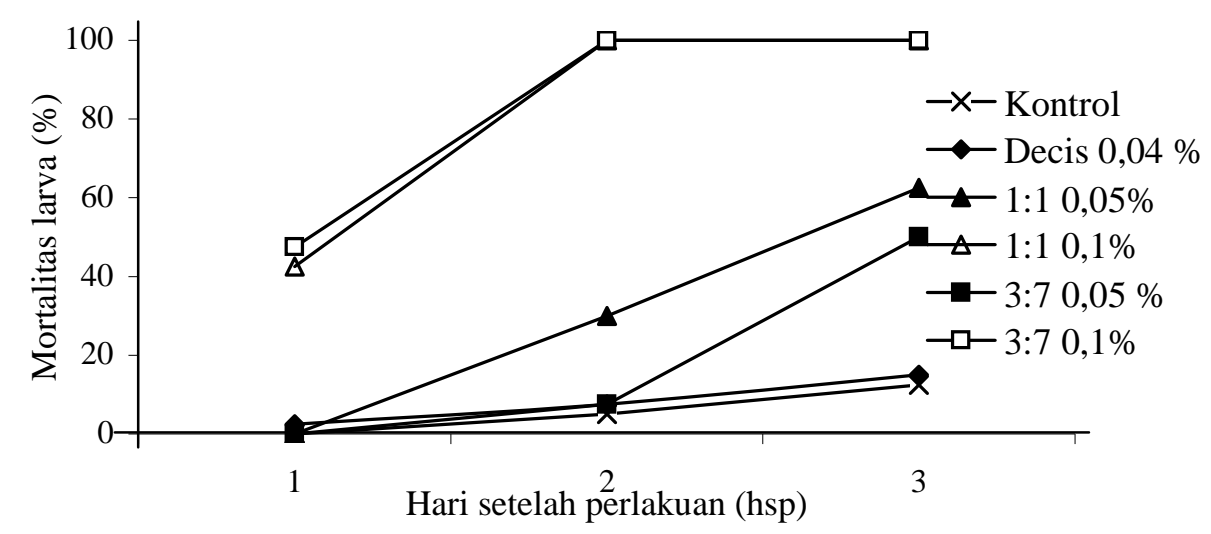

Gambar 3. Perkembangan mortalitas larva $C$. pavonana yang diperlakukan campuran ekstrak $P$. retrofractum dan $A$. squamosa dan insektisida pembanding padahari ke-2 pemaparan. 
yang rendah yaitu 2,8\% (Gambar 3).

Tingginya mortalitas larva pada tanaman yang dipaparkan 3 hari masih ditunjukkan oleh campuran ekstrak PA $1: 1 \quad 0,1 \%$ dan PA $3: 7 \quad 0,1 \%$ yang memberikan kematian larva berturut-turut $97,4 \%$ dan $100 \%$ pada 3 hsp, sedang campuran ekstrak PA 1:1 $0,05 \%$ dan PA $3: 7 \quad 0,05 \%$ hingga 3 hsp hanya menunjukkan kematian larva kurang dari $40 \%$. Insektisida pembanding deltametrin sendiri masih menunjukkan kematian larva yang rendah yaitu 5,3\% (Gambar 4).
Pemaparan 5 hari menunjukkan bahwa campuran ekstrak PA 3:7 0,1\% masih menunjukkan kematian larva yang tinggi yaitu $100 \%$ pada $3 \mathrm{hsp}$, sedangkan ketiga campuran ekstrak lainnya menunjukkan kematian larva kurang dari $60 \%$. Perlakuan PA $\quad 1: 1 \quad 0,1 \%$ dan PA $3: 7 \quad 0,05 \%$ menunjukkan kematian larva yang tidak berbeda nyata, yang menyebabkan kematian masing-masing $57,1 \%$ dan $42,9 \%$ pada 3 hsp. Mortalitas terendah ditunjukkan oleh perlakuan ekstrak PA 1:1 $0,05 \%$ yaitu 11,4\% (Gambar 5).

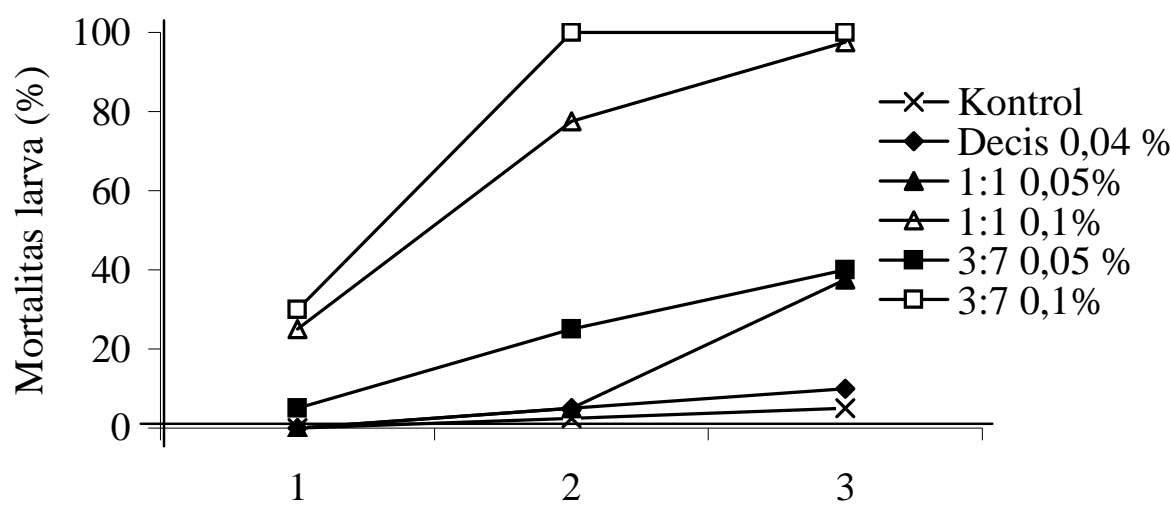

Hari setelah perlakuan (hsp)

Gambar 4. Perkembangan mortalitas larva $C$. pavonana yang diperlakukan campuran ekstrak $P$. retrofractum dan A. squamosa dan insektisida pembanding pada hari ke-3 pemaparan

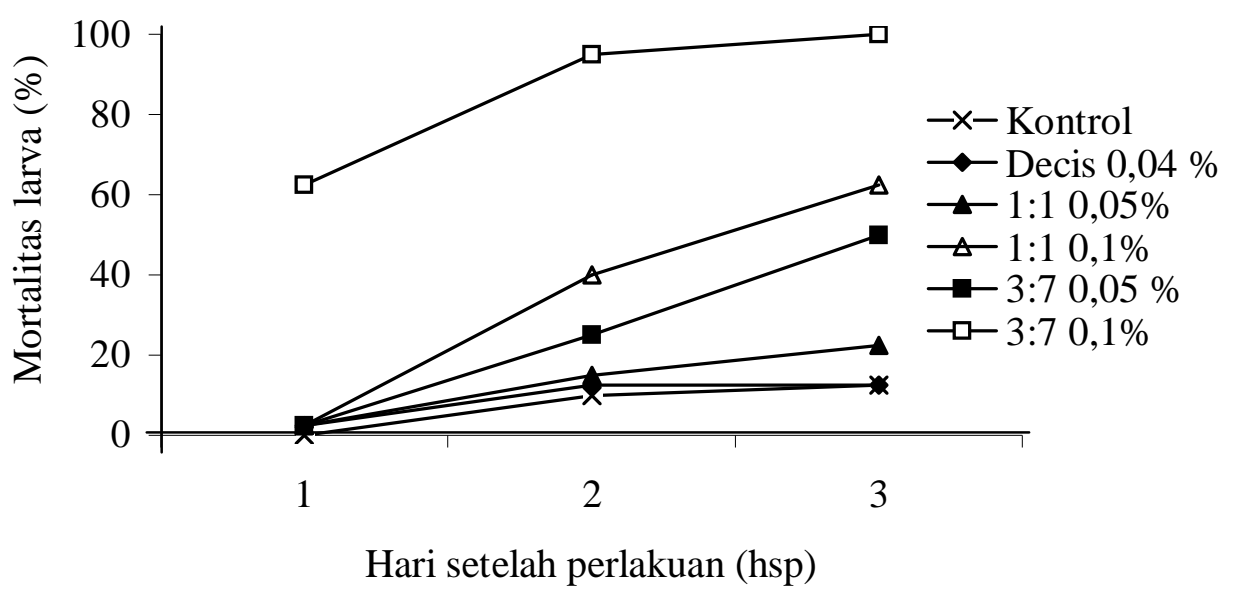

Gambar 5. Perkembangan mortalitas larva $C$. pavonana yang diperlakukan campuran ekstrak $P$. retrofractum dan A. squamosa dan insektisida pembanding pada hari ke-5 pemaparan 


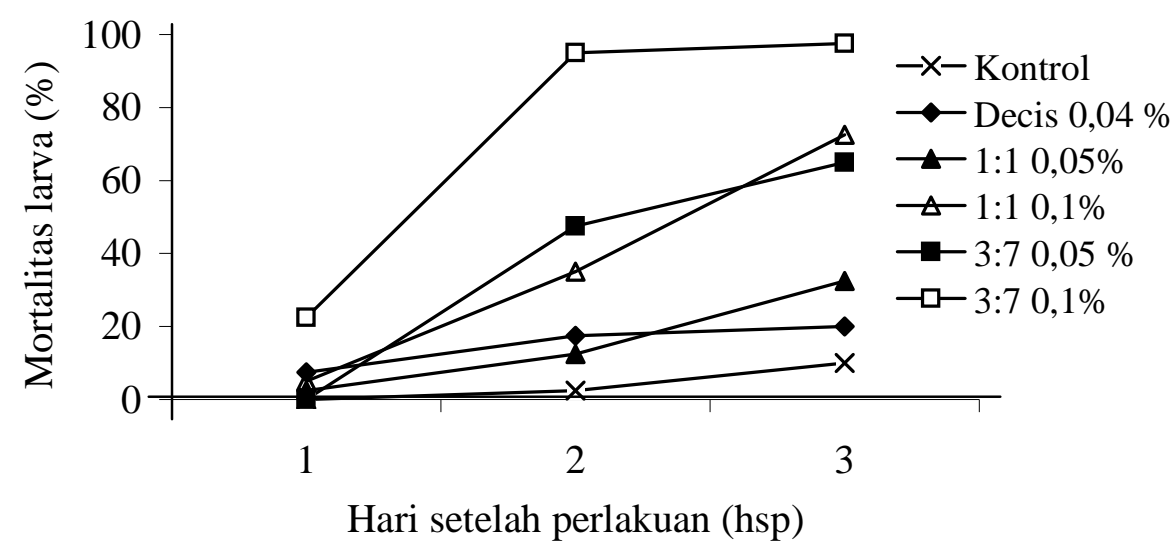

Gambar 6. Perkembangan mortalitas larva C. pavonana yang diperlakukan campuran ekstrak P. retrofractum dan A. squamosa dan insektisida pembanding pada hari ke-7 pemaparan

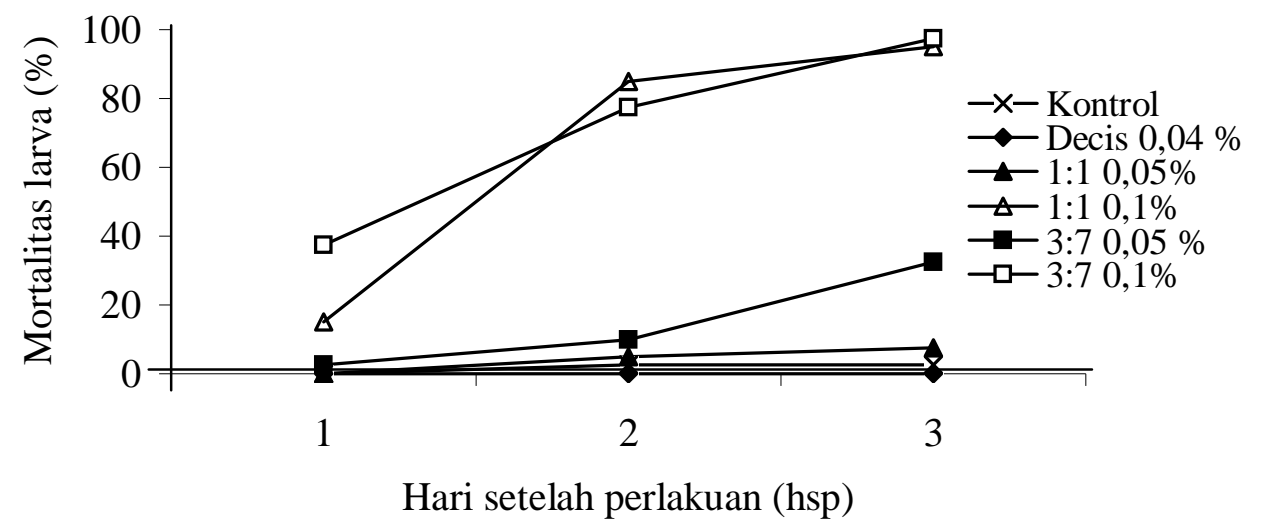

Gambar 7. Perkembangan mortalitas larva C. pavonana yang diperlakukan campuran ekstrak $P$. retrofractum \& A. squamosa dan insektisida pembanding pada hari ke-10 pemaparan

Perbandingan ekstrak $3: 7 \quad 0,1 \%$ masih menunjukkan mortalitas larva yang tinggi yaitu $97 \%$ walaupun setelah dipaparkan 7 hari. Sementara itu pada campuran ekstrak PA 1:1 0,1\% dan PA 3:7 $0,05 \%$ memberikan mortalitas larva sebesar $69,5 \%$ dan $61,1 \%$ dan campuran ekstrak tanaman PA 1:1 $0,05 \%$ menunjukkan mortalitas yang paling rendah yaitu $25 \%$ pada 3 hsp. Perlakuan insektisida pembanding memberikan persentase kematian yang sangat rendah yaitu $11,1 \%$ pada interval waktu pengamatan yang sama (Gambar 6).
Pada pemaparan hari ke-10, campuran ekstrak tanaman PA 3:7 0,1\% masih menunjukkan kamatian larva yang tinggi yaitu $97,4 \%$. Demikian juga dengan perlakuan campuran ekstrak PA $1: 10,1 \%$ yang memberikan kematian larva sebesar 94,9\%, sedang untuk perlakuan lainnya menunjukkan penurunan mortalitas yang cukup tinggi yaitu berturut-turut 5,1\% dan 30,8\% untuk campuran ekstrak PA 1:1 0,05\% dan PA 3:7 0,05\% (Gambar7). 
Pengaruh fitotoksik. Setelah dipaparkan selama 10 hari, tanaman yang diolesi campuran ekstrak $P$. retrofractum dan $A$. squamosa tidak menampakkan adanya gejala fitotoksik pada semua perbandingan dan konsentrasi uji, demikian juga dengan perlakuan insektisida pembanding deltamethrin.

\section{PEMBAHASAN}

Hasil pengujian di atas menunjukkan bahwa campuran ekstrak $P$. retrofractum dan A. squamosa hingga konsentrasi $0,05 \%$ memiliki aktivitas insektisida yang kuat terhadap mortalitas C. pavonana. Senyawa aktif kedua spesies ini telah berhasil diisolasi dan diidentifikasi dan cukup efektif sebagai insektisida. $P$. retrofractum mengandung senyawa piperlonguminin, silvatin, guinensin, piperlongumin, filfilin, sitosterol, dan metilpiperat (Katzer 2004). Pada buahnya mengandung piperin, kavicin, asam palmiat, minyak atsiri, yang mempunyai daya antipiretrik, analgesik, anti inflamasi, dan menekan susunan saraf pusat (Iptek, 2005).

Senyawa aktif $A$. squamosa dan umumnya famili Annonaceae yang bersifat insektisida termasuk dalam golongan asetogenin (Londershausen et al., 1991). Senyawa aktif ini selain bersifat sebagai insektisida juga bersifat anti tumor, anti bakteri, anti jamur, dan dapat menghambat pertumbuhan sel kanker (Zeng et al., 1996). Biji A. squamosa mengandung $42-45 \%$ lemak, annonain, dan resin yang bekerja sebagai racun perut dan racun kontak terhadap serangga (Kardinan, 2001). Berkaitan dengan sifat insektisidanya, squamosin dan asimisin yang termasuk dalam golongan asetogenin ini selain dapat menghambat perkembangan serangga juga dapat mematikan beberapa spesies serangga seperti $P$. xylostella, Callosobruchus chinensis (Coleoptera: Bruchidae) dan Nephotettix cincticeps (Homoptera: Jassidae). Ekstrak A. squamosa pada konsentrasi 0,1\%-0,5\% dilaporkan dapat mematikan larva $C$. pavonana $100 \%$ (Dadang, 1999).

Campuran ekstrak $P$. retrofractum dan $A$. squamosa yang diuji di laboratorium menunjukkan mortalitas larva yang tinggi sebesar $100 \%$ pada konsentrasi $0,05 \%$. Keefektifan campuran ekstrak ini ternyata juga memberikan hasil mortalitas yang tinggi terhadap $C$. pavonana pada pengujian semi lapangan. Kemampuan serangga untuk membentuk sistem pertahanan terhadap beberapa senyawa yang berbeda sekaligus lebih sulit daripada terhadap senyawa insektisida tunggal. Serangga tidak mudah menjadi resisten terhadap ekstrak tumbuhan dengan beberapa bahan aktif. Banyak senyawa tanaman yang memiliki cara kerja yang berbeda dengan insektisida sintetik yang umum digunakan saat ini, sehingga kemungkinan terjadinya resistensi silang cukup kecil (Prijono 1999). Selain itu, pencampuran beberapa insektisida botani juga dapat mengefisienkan sediaan bahan tanaman.

Pencampuran beberapa senyawa aktif tumbuhan dapat memberikan efek seperti sinergis, antagonis, atau netral. Dalam suatu ekstrak tumbuhan, selain beberapa senyawa aktif utama biasanya juga terdapat banyak senyawa lain yang kurang aktif, namun keberadaanya dapat meningkatkan aktivitas ekstrak secara keseluruhan (sinergi) (Prijono 1999). Yuswanti (2002) melaporkan bahwa campuran fraksi asetil asetat biji Aglaia harmsiana dan tangkai daun Dysoxilum acutangulum bersifat sinergis terhadap larva instar III $P$. xylostella pada $\mathrm{LC}_{50}$ tetapi bersifat antagonis pada $\mathrm{LC}_{95}$.

Aktivitas campuran ekstrak $P$. retrofractum dan A. squamosa yang diperlakukan pada C. pavonana setelah dipaparkan beberapa hari secara umum mengalami penurunan. Penurunan ini disebabkan rendahnya kandungan senyawa aktif yang tertinggal pada sediaan yang terdapat pada daun perlakuan setelah disemprotkan. Rendahnya kandungan senyawa aktif ini dapat dikarenakan akumulasi dari berbagai faktor. Setelah waktu tertentu, kandungan insektisida dapat mengalami perubahan. Senyawa aktif dapat mengalami degradasi yang dapat disebabkan oleh berbagai faktor seperti faktor biologi (mikroorganisme), kimia, dan fisik (cahaya matahari/fotodegradasi), sedangkan perpindahan dapat dipengaruhi oleh faktor fisik lainnya seperti aliran air, dan udara (Syahputra 2004). Pada percobaan ini degradasi senyawa aktif oleh mikroflora yang terdapat di permukaan daun brokoli, reaksi kimia senyawa aktif, serta fotodekomposisi oleh sinar ultraviolet dapat terjadi. Insektisida asal tumbuhan mudah terurai oleh cahaya matahari sehingga memiliki persistensi yang singkat di lapangan. Persistensi merupakan jangka waktu senyawa aktif insektisida masih mempunyai aktivitas biologi. Persistensi insektisida dapat dipengaruhi oleh radiasi sinar matahari dan curah hujan. Radiasi sinar matahari terutama sinar 
ultraviolet memiliki kontribusi yang nyata dalam mempengaruhi persistensi insektisida di alam (Matsumura 1985). Setelah dipaparkan 1 hari, aktivitas campuran ekstrak PA menurun kecuali PA $3: 7 \quad 0,1 \%$ yang tetap konstan hingga hari ke-10 pemaparan yang memberikan mortalitas tinggi hingga di atas $97 \%$. Hasil ini menunjukkan bahwa campuran ekstrak PA 3:7 0,1\% tidak hanya efektif dalam memberikan mortalitas yang tinggi terhadap C. pavonana tetapi juga memberikan ketahanan yang cukup lama di lapangan. Sementara itu faktor curah hujan yang memberikan pengaruh persistensi insektisida diabaikan dalam penelitian ini, karena tanaman yang dipaparkan dipindahkan ke tempat terlindung apabila turun hujan untuk mengetahui ketahanan insektisida selama pemaparan 10 hari di bawah sinar cahaya matahari.

Berkaitan dengan keamanan sediaan ekstrak tumbuhan yang digunakan dalam pengaplikasian insektisida botani, adanya gejala fitotoksik yang terjadi pada tanaman perlu diperhatikan. Senyawasenyawa non polar yang berwujud minyak seringkali bersifat fitotoksik dan hormon pertumbuhan tanaman yang terlarut dalam air dapat mempengaruhi pertumbuhan tanaman (Prijono, 1999). Sediaan ekstrak terdiri dari banyak gabungan senyawa artinya pada ekstrak kasar selain terdapat senyawa aktif juga mengandung komponen-komponen lain. Ekstrak metanol dapat terdiri dari komponen polar hingga komponen non polar. Komponen non polar yang berwujud minyak atau cairan pekat dapat merusak lapisan lilin kutikula daun atau membran sel daun tanaman. Sementara dalam keadaan murni, banyak senyawa aktif yang berbentuk padatan dan tidak fitotoksik pada konsentrasi yang aktif terhadap hama sasaran (Prijono, 1999). Pada percobaan ini, semua campuran ekstrak yang dipaparkan hingga hari ke-10 tidak memperlihatkan adanya gejala fitotoksisitas sehingga aman untuk diaplikasikan dalam upaya menurunkan populasi $C$. pavonana. Namun demikian pengujian pada lahan yang lebih luas perlu dilakukan.

\section{SIMPULAN}

Persistensi campuran ekstrak Piper retrofractum dan Annona squamosa pada konsentrasi 0,1\% menunjukkan efektifitas yang tinggi hingga pemaparan hari ke-10. Semua campuran ekstrak pada perbandingan 1:1 dan 3:7 dan konsentrasi $0,05 \%$ dan
0,1\% tidak menunjukkan adanya pengaruh fitotoksik pada tanaman brokoli hingga hari ke-10 pemaparan.

\section{SANWACANA}

Pada kesempatan ini diucapkan terimakasih kepada Academic Frontier Research Project, Tokyo University of Agriculture atas pendanaan penelitian ini. Ucapan terimakasih juga disampaikan kepada Sdr. Ratna Sari Dewi, SP dan Sdr. Agus Sudrajat atas bantuan teknisnya dalam penelitian ini.

\section{DAFTAR PUSTAKA}

Dadang. 1999. Sumber insektisida alami. dalam: Nugroho BW, Dadang, Prijono D, penyunting. Bahan Pelatihan Pengembangan dan Pemanfaatan Insektisida Alami; Bogor, 9-13 Agustus 1999. Bogor: Pusat Kajian Pengendalian Hama Terpadu, Institut Pertanian Bogor.

Dono, D. 2004. Aktivitas insektisida rokaglamida dan penghambatan respons imunitas larva Crocidolomia pavonana (Fabricus) terhadap parasitoid Eriborus argenteopilosus (Cameron) [disertasi]. Bogor: Sekolah Pascasarjana, Institut Pertanian Bogor.

Gusfi, V. 2002. Persepsi petani sayuran di Cipanas terhadap insektisida sintetis dan botani. skripsi. Bogor: Jurusan Hama dan Penyakit Tumbuhan, Fakultas Pertanian, Institut Pertanian Bogor.

Iptek. 2005. Tanaman Obat Indonesia. http://www.iptek.net.id/ind/cakra obat/ tanamanobat.php?id=108. [21 November 2005]

Kardinan, A. 2001. Pestisida Nabati: Ramuan dan Aplikasi. Jakarta: Penebar Swadaya.

Katzer, G. 2004. Long Pepper (Piper longum L. and Piper retrofractum Vahl). http://www.unigraz.at/ katzer/engl/generic_fra me.html?Pipe_lon.html. [12 Januari 2006].

Londershausen, M, W. Leicht, F. Lieb, H. Moeschler \& H. Weiss. 1991. Annonins-mode of action of acetogenins isolated from Annona squamosa. 
Pesticide Science 33(4): 443-445. http://www.soton.ac.uk/ icuc/an-sq-bib/an-sqa2.htm\#ref416. [12 Januari 2006].

Matsumura, F. 1985. Toxicology of Insecticides, 2nd ed. Plenum Press, New York.

Metcalf, R.L. 1986. The ecology of insecticides and the chemical control of insects. Di dalam: Kogan M, editor. Ecological Theory and Integrated Pest Management Practice. New York: John Wiley \& Son.

Prijono, D. 1999. Pemanfaatan insektisida alami di tingkat petani. Di dalam: Nugroho BW, Dadang, Prijono D, penyunting. Bahan Pelatihan Pengembangan dan Pemanfaatan Insektisida Alami; Bogor, 9-13 Agustus 1999. Bogor: Pusat Kajian Pengendalian Hama Terpadu Institut Pertanian Bogor. hal 82-86.

Prijono, D. 1999. Prospek dan strategi pemanfaatan insektisida alami dalam PHT. Di dalam: Nugroho BW, Dadang, Prijono D, penyunting. Bahan Pelatihan Pengembangan dan Pemanfaatan Insektisida Alami; Bogor, 9-13 Agustus 1999. Bogor: Pusat Kajian Pengendalian Hama Terpadu, IPB. hal 1-7.

Rauf, A, D. Prijono, Dadang, I.W. Winasa \& D.A. Russel. 2005. Survey on Pesticide Use by Cabbage Farmers in West Java, Indonesia. Report of Research Collaboration between Dept. of Plant Protection-IPB with LaToobe University, Australia.

SAS Institute. 1990. SAS/STAT User's Guide, Version 6, Vol.2. $4^{\text {th }} \mathrm{ed}$. Cary (North Carolina): SAS Institute.

Sastrosiswojo, S. \& W. Setiawati. 1992. Biology and Control of Crocidolomia binotalis in Indonesia. Di dalam: Talekar NS, editor. Diamondback Moth and Other Crucifer Pests. Proceed. the Second International Workshop; Tainan, 10-14 December 1990. Taiwan. Asian Vegetable Research and Development Centre. hlm 81-87.
Sastrosiswojo, S. 1996. Sistem Pengendalian hama terpadu dalam menunjang agribisnis sayuran. Di dalam: Duriat AS, Basuki RS, Sinaga RM, Hilman T, Abidin Z, penyunting. Prosiding Seminar Ilmiah Nasional Komoditas Sayuran; Lembang, 24 Oktober 1995. Bandung. Balai Penelitian Tanaman Sayuran. hlm 69-83.

Steel, R.G.D. \& J.H. Torrie. 1993. Prinsip dan Prosedur Statistik: Suatu Pendekatan Biometrik. Ed ke-2. Sumantri B, penerjemah. Jakarta: PT Gramedia Pustaka Utama. Terjemahan dari: Principles and Procedure of Statistics.

Syahputra, E. 2004. Bioaktivitas Calophyllum soulattri Burm. f. (Clusiaceae) sebagai alternatif insektisida botani baru Disertasi. Bogor: Sekolah Pascasarjana, IPB.

Uhan, T.S. 1993. Kehilangan hasil panen kubis karena ulat krop kubis Crocidolomia binotalis Zeller. (Lepidoptera: Pyralidae) dan cara pengendaliannya. Bul Penel Hort 3(2): 22-26.

Wachjadi, M, Herminanto \& E. Pramono. 2001. Residu pestisida pada beberapa macam sayuran di Kabupateen Banyumas. Prosiding Kongres Nasional XVI dan Seminar Ilmiah. Bogor, 2224 Agustus 2001. Bogor: Perhimpunan Fitopatologi Indonesia. hlm 251-253.

Yuswanti, L. 2002. Pengaruh campuran ekstrak Aglaia harmsiana Perkins dan Dysoxylum acutangulum Miq. (Meliaceae) terhadap mortalitas dan oviposisi Plutella xylostella (L.) (Lepidoptera: Yponomeutidae). Skripsi. Bogor: Jurusan Hama dan Penyakit Tumbuhan, Fakultas Pertanian, Institut Pertanian Bogor.

Zeng, L., Q. Ye, N.H. Oberlies, G. Shi, Z.M. Gu, K. He \& J.L. Mclaoughlin. 1996. Recent advances in annonaceous acetogenins. Natural Product reports. 